\title{
土木学会論文報告集
}

第 332 号・1983 年 4 月

【論

文】

\section{鉄道沿線における環境影響の総合評価法について \\ EVALUATING METHOD FOR ENVIRONMENTAL EFFECTS OF URBAN RAILWAY}

河 上 省 吾*.青 島 縮 次 郎** - 陸 井 一 嘉*** By Shogo KAWAKAMI, Naojiro AOSHIMA and Kazuyoshi KUGAI

\section{1.はじめに}

本研究は，鉄道計画に際し，予測される環境污 染のあらゆる可能性を計画の段階において十分科 学的に検討し, 沿線環境保全をも考慮した総合的 な計画策定法の確立を目指すためのものである. また，現在，環境污染にさらされている沿線住民 の実態を調查分析し，その環境の改善を図るため の, 沿線住民のコンセンサスの得られる沿線整備 計画の策定法を確立することも目的としている.

さて，鉄道計画の評価はいくつかの評価システ ムによってなされるが, 本研究が対象とするシス テムは環境評価システムであり，それをこの鉄道 計画のトータルシステムの中に位置づけ, フロー チャート亡して簡潔に示したのが 図一1である.

この内容をみていくと，まず国民経済社会に関 する基本計画に基ゔいて，土地利用計画が策定さ れる. そして, ゾーニングが施された後, 発生・

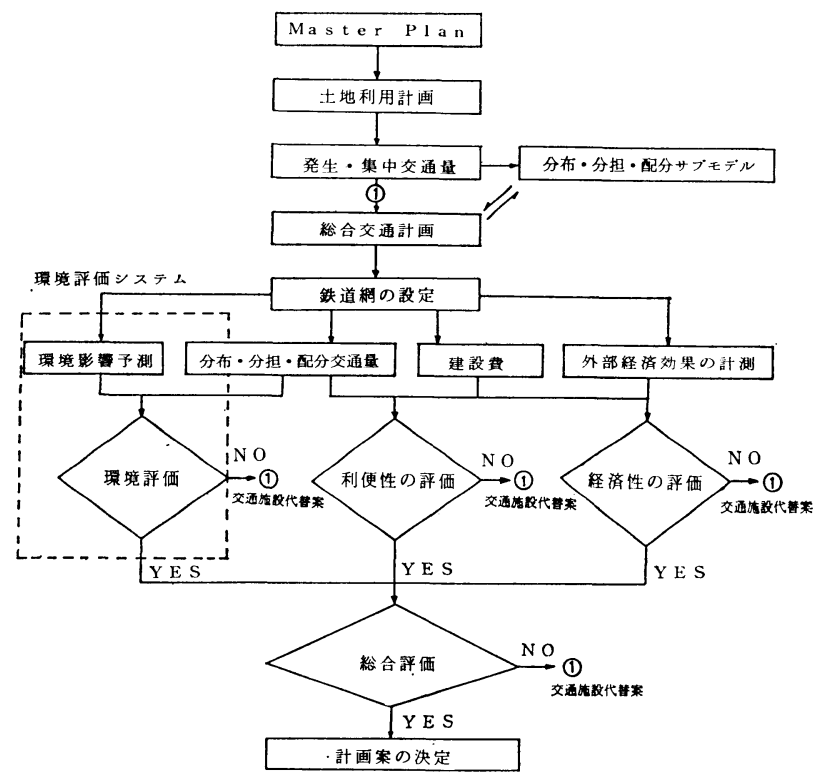

図一1 䌊合評価システム

集中交通量が求められ，既存の交通施設を考虑して，種 種の交通条件のもとにサブモデルで分布，分担，配分交 通量を算出し，新しい交通施設が設定される.これらの サブモデル間のフィードバック操作を繰り返しながら, 総合交通計画が決定され，その計画案の中で鉄道網の代 替案が設定される.代替案が設定されると，これらの代 替案に抢ける環境影響, 配分交通量, 建設費, 外部経済 効果などが予測され，それぞれに対する複数の価值観の 異なる評価主体 (たとえば利用者, 運営者, 沿線住民) による評価が成される．それらは利用者にとってその利 便性において望ましい交通サービスの最低水準を満足し ているか, また, 運営者にとってその時点における経済

\footnotetext{
* 正会員 工博 名古屋大学教授 工学部

** 正会員 工博 豊橋技術科学大学助教授

*** 正会員 工修 川崎重工
}

水準に照らして満足すべき経済性を有しているか, そし て, 本研究の主題である沿線住民にとって, 納得のいく 環境条件を満たしているかなどである.

さて, 本研究で取り扱う環境評価システムとは, 図一 1 において，破線で囲んだ評価システムであり，ここで いう環境の意味するところは, 沿線居住者にとっての環 境であり, 利便性, 経済性の評価システムとは独立した ものとして位置づけている.

個々の評価システムのすべてにおいて受け入れられた 代替案は利便性, 経済性, 環境の側面から比較がなされ て,それが総合評価され鉄道施設計画の第 1 次的な決定 がなされるのである. また，鉄道網代替案が，いずれか の評価システムにおいて受け入れられなかった場合は, 再び上記プロセスの需要推計に, あるいは土地利用計画 の段階までフィードバックすることになる. 


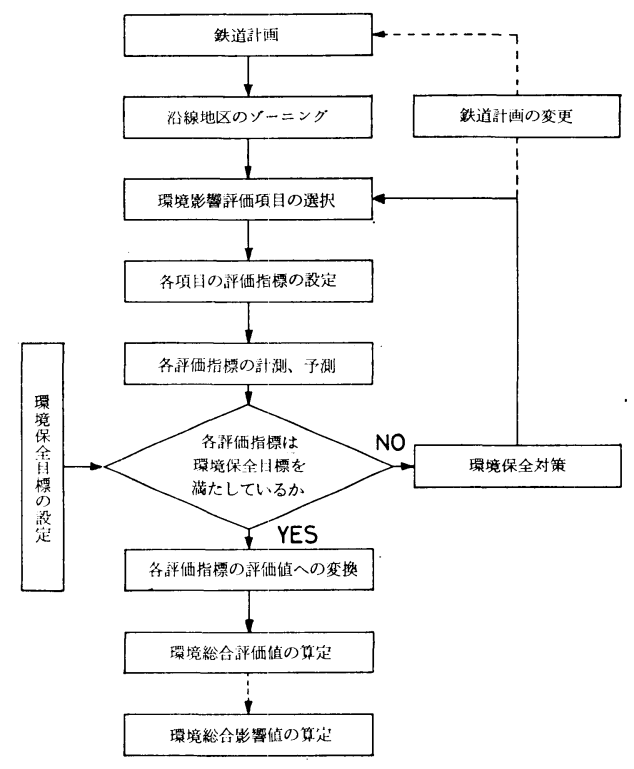

図一2 環境評価システム

次に，環境評価システムの内容であるが，これまでこ の分野の研究が多く行われているのは道路計画において である. 從来用いられている鉄道計画における環境評価 システムは，道路計画における環境評価システム ${ }^{1), 2) を ~}$ 踏襲したものであり，そのシステムの主なフローを図一 2 に示す.

以上が鉄道計画における総合評価システムと環境評価 システムの概要であるが，次に，本研究の構成とおもな 内容を示すと以下のとおりである.まず第 1 に, 研究の 背景，目的を述へ，鉄道計画において本研究がどのよう な位置にあるか, また，本研究の大まかな構成について 述べる. 第 2 に，まず鉄道沿線における環境評価システ ムを構築していくうえでの資料となる物理的, 心理的調 查の方法を述べ，その適用結果を示し，またその中で， どのように環境影響評価項目を選択して計画との因果関 係を考慮したかを示す. 第 3 に, 調查で得られたデータ をもとに，鉄道沿線における各評価項目の計測值を得る ための方法について考察し, 計測された物理量と住民意 識調查から得られる人間の心理量との関係を定量的に分 析し, 各項目の個々の評価方法を検討し, 環境評価値に 変換する方法を述べる．第 4 に，環境総合評価值を得る ための，環境評価值に対する客観的なウエイトをつける 方法について, 種々の方法を用いて検討する.さらに, 鉄 道計画の代替案を環境面から総合評価できる形にするた めに, 全路線における環境総合影響值を算出する方法を 紹介する. 第 5 に, 鉄道計画の総合評価を可能にするア プローチとして, 環境評価システムと同様の方法で求め られた利便性の総合評価值と環境総合評価值を用い，住 民意識調査から, 環境と利便のトレードオフの関係を考
虑した総合評価值を求める方法を検討する．ここでは, 利用者でありかつ環境被害者であるといら沿線住民の立 場より, 環境と利便のウエイトゔけの問題を考察するこ とを目的としている.

\section{2. 鉄道沿線における環境調査}

環境実態調査の方法を大別すると, 各環境影響評価項 目の物理的な量を測定することと, 意識調査を行うこと である. 本調查では, 名古屋市周辺での在来鉄道を中心 に，鉄道が沿線地域に与える影響に関するアンケート調 查と, その地域での騒音值の実測を行った.

\section{（1）被害意識調査}

住民意識調查は, 名古屋鉄道 (名鉄) 犬山線, 常滑 河和線, 瀬戸線および国鉄中央本線の沿線の住居地域を 対象とし, 昭和 52 年 6 月, 昭和 52 年 11 月, 昭和 54 年 10 月の 3 回にわたって調查したものである. 図一3, 表 -1 はこの調查対象地区, 調查日時および回収状況を示 したものである. なおこの調査地区の 1 ～地区は，以 前に 1 度, 浅野俊樹によって分析されている ${ }^{3}$.

調査地区は道路の場合, 環境への影響範囲は最も広い 場合でも数百 $\mathrm{m}$ であるという過去の分析結果 ${ }^{4}$ を受け て, 鉄道の軌道中心から $120 \mathrm{~m}$ の範囲でランダムに調 查世帯のサンプリングを行った. 軌道の形態別には, 平 面部 4 地区, 盛土部 2 地区, 道路と鉄道の両方からの環 境被害を受けていると思われる複合污染地区 2 地区を選 定し，全地区から有效個人サンプル 3769 を得た（以 後, 各地区を 表一1 のように 1 8 地区とよぶ).

調査は限定された地区内においては，家庭訪問法が最 も望ましいという過去の事例 ${ }^{1}$ により, 調査員の戸別訪 問によるアンケート票の留め置き方式で行い, 調査対象 者は 13 歳 (中学生) 以上とした.

アンケートの設計は調查目的, 分析方法と密接な関係 がある. 特に, 環境影響評価項目の選定が可能なかぎり 網羅的であることは，環境評価システムを構筑していく らえでの大原則であるが，本研究ではその評価主体が住 民であり，住民が被害として意識することのできる以下 の 10 の評価項目を選んだ.

(1) 騒音, (2) 振動, (3) 電波障害, (4) 日照・通風の障 害, (5) 粉塵, (6) 景観破壊, (7) 地区分断, (8) プライ バシーの侵害, (9) 事故の不安, (10) 子供の線路内への 侵入に対する不安.

アンケートの質問は大きく分けて「属性」「各評価項 目に対する環境被害，不安に関する意識」「鉄道の交通 サービスに関する意識」「総合的にみた評価」の 4 つよ りなる. すなわち, 属性分析を行らために, 年齢や日常 


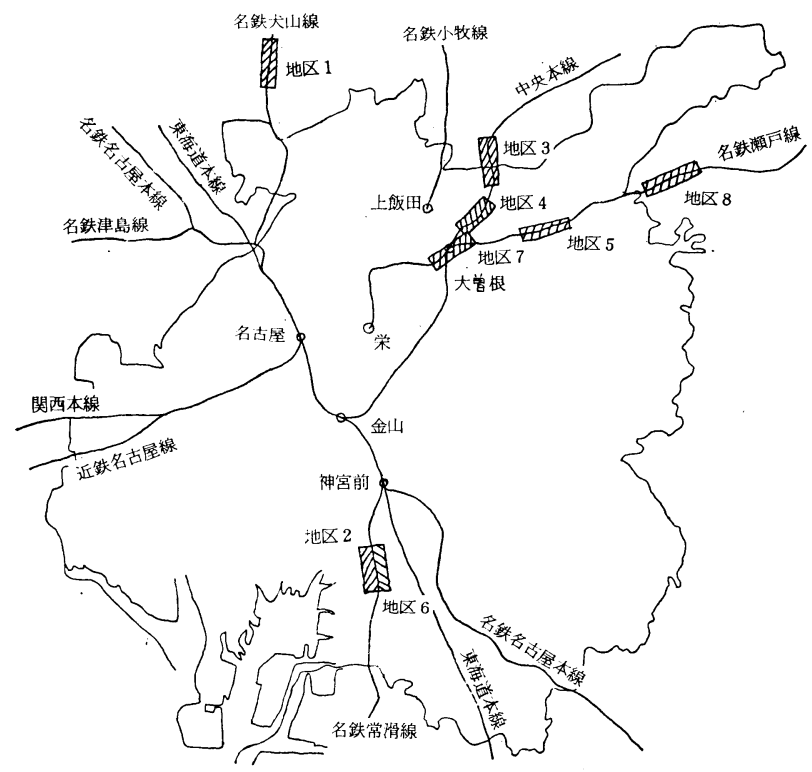

図一3 住民意識調查対象地区
ネルデータレコーダにインプットして, 後にレベ ルレコーダに書き出すという方法をとった.

\section{（3）調査対象地区の環境特性}

本研究の調査対象地区は鉄道沿線の人口密度の 高い地域であるが, 特に, 地区 4 は大曽根周辺の 旧市街地に含まれ，地区 $6,7,8$ は名鉄沿線に 古くから発達した地区であり，住民の半数以上が 戦前より居住している. 一方, 地区 3 は名古屋市 の北側に位置する新興住宅地であり，住民の 7 割 近くが戦後住みついている. 鉄道利用頻度を地区 ごとにみると, 地区 6,7 が高く地区 4 は低い. これは地区 4 では地下鉄，バスなど競合交通機関 の便が良く，地区 6,7 では競合交通機関の便が 悪いためであると考えられる.

\section{3. 鉄道沿線における環境影響評価の 方法}

表一1 住民意識調查対象地区の概要と回収状況

\begin{tabular}{|c|c|c|c|c|c|c|c|c|}
\hline $\begin{array}{l}\text { 地区 } \\
\text { No. }\end{array}$ & 鉄道路線名 & 地 区 名 & $\begin{array}{l}\text { 配布 } \\
\text { 世带 }\end{array}$ & $\begin{array}{l}\text { 回坚 } \\
\text { 世带 }\end{array}$ & $\begin{array}{l}\text { 回収率 } \\
(\%)\end{array}$ & $\begin{array}{l}\text { 有効個人 } \\
\text { 全ンブル数 }\end{array}$ & $\begin{array}{l}\text { 個人サンブル } \\
\text { 数/世带数 }\end{array}$ & 調査日時 \\
\hline 1 & 名鉄犬山線 & 愛知県 西春町 & 228 & 224 & 98.2 & 535 & 2.39 & S52. 6月 \\
\hline 2 & 名鉄常滑線 & 名古屋市 道徳 & 218 & 211 & 96.8 & 528 & 2.50 & " \\
\hline 3 & 国鉄中央本線 & 名古屋市 幸心 & 160 & 157 & 98.1 & 360 & 2.29 & $"$ \\
\hline 4 & 国鉄中央本線 & 名古屋市 山田 & 154 & 150 & 97.4 & 395 & 2.63 & " \\
\hline 5 & 名鉄瀬戸線 & 名古屋市 守山 & 234 & 230 & 98.2 & 532 & 2.31 & S52.11月 \\
\hline 6 & 名鉄常滑線 & 名古屋市 道徳 & 228 & 196 & 94.7 & 545 & 2.52 & $"$ \\
\hline 7 & 名鉄瀬戸線 & 名古屋市＼cjkstart東 & 200 & 186 & 93.0 & 489 & 2.63 & S 54.10月 \\
\hline 8 & 名鉄 瀬戸線 & 愛知県尾張九旭市 & 256 & 232 & 90.6 & 529 & 2.28 & $"$ \\
\hline
\end{tabular}

\section{（1） 評価方法の現状}

環境影響評価に関する定量的評価の 試みは,アメリカの「国家環境政策法」 にその端を発した. それを受けて，わ が国においても国土開発技術研究セン ター ${ }^{5)}$ や建設省土木研究所 ${ }^{2}$ などが, ア メリカの Battelle 研究所の評価関数 法6)の考え方を応用してカテゴリカル

生活パターンなどの属性を質問しなくてはならないし, 項目別の不満や被害頻度の相対的な関係を分析するため には，環境に対する個別的および総合的な質問がなされ なければならない. また, 本研究では各評価項目の対策 要望順位を質問しており,この分析により評価項目相互 間の関係を把握するとともに, 各評価項目の相対的ウエ イトづけを行おうとするものである.

\section{（2）騒音実測}

意識調査と併行して, 各地区 1 か所ずつ合計 8 か所で 騒音実測を行った.

騒音の測定器は指示騒音計 (JIS C 1502) を用い, 動 特性は Slow, 補正回路は A 特性とした. 測定地点は線 路に対して直角に地区内人軌道中心から $10 \mathrm{~m}, 20 \mathrm{~m}, 40$ $\mathrm{m}, 80 \mathrm{~m}$ の位置に騒音計を設置し, 三脚を用いて地上 $1.2 \mathrm{~m}$ になるように調整した. また, 暗騒音や反射音の 影響の少ない場所を選んだ。

実測は車両通過ごとに最低 8 回行い，記録はそれぞれ の騒音計のアウトプットを同軸コードを通して 4 チャン
な尺度を用い, 環境状態の最も悪いカテゴリーの効果を 0 , 最も良いカテゴリーの効果を 1 に対応させて 評価す る方法を提案している. また, 個別的にみれば, 地区分 断や緑量に対して, 徒歩距離や緑面積を用いて評価する 研究7)などもあるが，現段階において予測手法がほぼ確 立している環境影響評価項目は騒音のみであり, 他の評 価項目については実用的な方法の開発はまだ不十分な段 階であるといえる. 加えて, 評価の問題についてもその 基準として要請基準や環境基準があるが, 個々の評価項 目の物理量とそれに対する人間の意識反応の関連がすべ て明確にとらえられているわけではない. したがって個 個の項目の環境への影響を評価する方法も, 現段階では 模索の状態であるといってよいであろう.

鉄道関係においては, 新幹線を対象に 1975 年 7 月に 環境庁告示による騒音の環境基準, 1976 年 3 月には振動 に関する要請基準が設定された. これは中央公害審議会 の答申に基づいたものであり, 評価方法は騒音・振動と もピークレベルを用いることとしている.

一方，在来線鉄道に関しては現在のところ基準が定め 
られるに至っていないが, 在来線沿線住民の 表一3 カテゴリーの内容

騒音, 振動等に対する苦情件数は, 近年特に 増加の傾向にある.こうしたことから, 騒音, 振動等を中心として早急に在来線鉄道の環境 影響評価の方法の確立が望まれている.

\section{（2）環境影響評価項目に関する被害意識 の要因分析}

環境影響を定量的に評価するためには，鉄

\begin{tabular}{|c|c|c|c|c|c|c|c|}
\hline & 年 令 & 居住歴 & 家の形態 & 見通し & 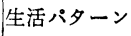 & 就㖟時刻 & 距 \\
\hline 1 & ～19才 & 1 年以内 & $\begin{array}{l}\text { 持家 } \\
3 \text { 部屋まで }\end{array}$ & $\begin{array}{l}\text { 上く見通 } \\
\text { せる }\end{array}$ & $\begin{array}{l}1 \text { 日中家に } \\
\text { いる }\end{array}$ & 10時以前 & $\sim 20 \mathrm{~m}$ \\
\hline 2 & 20〜29才 & 3 年以内 & $\begin{array}{l}\text { 持家 } \\
3 \sim 6 \text { 部屋 }\end{array}$ & $\begin{array}{l}\text { 部分的 } \\
\text { 遮られる }\end{array}$ & $\begin{array}{l}\text { 朝出て夜帰 } \\
\text { 马 }\end{array}$ & 10 11時 & $21 \sim 40$ \\
\hline 3 & $30 \sim 39 才$ & 10年以内 & 持家 6〜 & $\begin{array}{l}\text { 皆較的 } \\
\text { 的え }\end{array}$ & 一定時間出 & $11 \sim 12$ 時 & $41 \sim 60 \mathrm{~m}$ \\
\hline 4 & $40 \sim 49 才$ & 戦 後 & $\begin{array}{l}\text { 借家 } \\
3 \text { 部屋まで }\end{array}$ & $\begin{array}{l}\text { 戒られる } \\
\text { 部分 }\end{array}$ & $\begin{array}{l}\text { 外出時間は } \\
\text { 一定しない }\end{array}$ & $0 \sim 1$ 時 & $61 \sim 80 \mathrm{~m}$ \\
\hline 5 & 50〜59オ & 戦 前 & 借家 3 & $\begin{array}{l}\text { まったく見 } \\
\text { 通せない }\end{array}$ & 出たり入っ & 1 時以降 & \\
\hline 6 & $60 才 \sim$ & & & & その他 & & $101 \mathrm{~m}$ 以上 \\
\hline
\end{tabular}
道沿線住民に関する物理的, 心理的諸量を用 いて，各評価項目の影響を尺度化するクライテリアを明 確にしなければならない。 また, 各評価項目に対する被 害意識は各人の属性, 住居要因, 生活要因などで異なる と考えられ，これら諸要因と被害意識との関係を把握し なければならない。これらの関係を把握するために，本 研究では鉄道沿線の住民に対して，各評価項目に関する 被害について意識調査を行った.

住民意識調査では各評価項目に対して被害の程度を 「いつも感じる」「しばしば感じる」「時々感じる」「あま り感じない」「まったく感じない」の 5 段階で質問した. 本研究ではこの被害意識を外的基準とし, 以下の 7 要因 を説明変数とし，4〜6 にカテゴライズして 数量化理論

\section{表一2 騒音被害の要因分析}

\begin{tabular}{|c|c|c|c|c|c|c|c|}
\hline & & \multicolumn{3}{|c|}{ 地 区 1} & \multicolumn{3}{|c|}{ 地 区 2} \\
\hline & & $\begin{array}{l}\text { サンプ } \\
\text { ル数 }\end{array}$ & $\begin{array}{l}\text { カテゴリー } \\
\text { スコア }\end{array}$ & レンジ & $\begin{array}{l}\text { サンプ } \\
\text { ル数 }\end{array}$ & $\begin{array}{l}\text { カテゴリー } \\
\text { スコア }\end{array}$ & レンジ \\
\hline 令 & $\begin{array}{l}1 \\
2 \\
3 \\
4 \\
5 \\
6\end{array}$ & $\begin{array}{r}49 \\
112 \\
112 \\
85 \\
42 \\
38\end{array}$ & $\begin{array}{r}-0.20 \\
0.01 \\
0.05 \\
0.10 \\
-0.01 \\
-0.12\end{array}$ & $\begin{array}{r}0.30 \\
(7)\end{array}$ & $\begin{array}{l}68 \\
80 \\
72 \\
76 \\
46 \\
36\end{array}$ & $\begin{array}{r}-0.29 \\
0.20 \\
0.13 \\
0.17 \\
-0.25 \\
-0.20\end{array}$ & $\begin{array}{r}0.49 \\
(6)\end{array}$ \\
\hline $\begin{array}{l}\text { 居 } \\
\text { 住 } \\
\text { 歴 }\end{array}$ & $\begin{array}{l}1 \\
2 \\
3 \\
4 \\
5\end{array}$ & $\begin{array}{r}26 \\
49 \\
125 \\
108 \\
130\end{array}$ & $\begin{array}{r}0.43 \\
0.33 \\
0.10 \\
-0.44 \\
0.06\end{array}$ & $\begin{array}{r}0.87 \\
(2)\end{array}$ & $\begin{array}{r}16 \\
17 \\
77 \\
221 \\
47\end{array}$ & $\begin{array}{r}-0.31 \\
-0.20 \\
0.36 \\
-0.12 \\
0.15\end{array}$ & $\begin{array}{r}0.67 \\
(5)\end{array}$ \\
\hline $\begin{array}{l}\text { 家 } \\
\text { ⿹ } \\
\text { 形 } \\
\text { 態 }\end{array}$ & $\begin{array}{l}1 \\
2 \\
3 \\
4 \\
5\end{array}$ & $\begin{array}{r}4 \\
139 \\
161 \\
65 \\
69\end{array}$ & $\begin{array}{r}0.08 \\
0.15 \\
0.10 \\
-0.18 \\
-0.36\end{array}$ & $\begin{array}{r}0.51 \\
(5)\end{array}$ & $\begin{array}{r}12 \\
149 \\
136 \\
41 \\
40\end{array}$ & $\begin{array}{r}-0.24 \\
-0.24 \\
0.22 \\
0.04 \\
0.18\end{array}$ & $\begin{array}{c}0.42 \\
(7)\end{array}$ \\
\hline $\begin{array}{l}\text { 見 } \\
\text { 通 } \\
\text { 乙 }\end{array}$ & $\begin{array}{l}1 \\
2 \\
3 \\
4 \\
5\end{array}$ & $\begin{array}{r}154 \\
72 \\
80 \\
90 \\
42\end{array}$ & $\begin{array}{r}0.22 \\
0.35 \\
-0.41 \\
-0.12 \\
-0.37\end{array}$ & $\begin{array}{c}0.63 \\
(4)\end{array}$ & $\begin{array}{r}142 \\
93 \\
41 \\
75 \\
27\end{array}$ & $\begin{array}{r}0.44 \\
-0.18 \\
-0.15 \\
-0.31 \\
-0.57\end{array}$ & $\begin{array}{r}1.01 \\
(3)\end{array}$ \\
\hline $\begin{array}{l}\text { 生 } \\
\text { 活 } \\
\text { 分 } \\
\text { 夕 } \\
1 \\
\text { ン }\end{array}$ & $\begin{array}{l}1 \\
2 \\
3 \\
4 \\
5 \\
6\end{array}$ & $\begin{array}{r}100 \\
219 \\
25 \\
62 \\
27 \\
5\end{array}$ & $\begin{array}{r}-0.16 \\
-0.04 \\
0.13 \\
0.09 \\
0.57 \\
0.28\end{array}$ & $\begin{array}{c}0.73 \\
(3)\end{array}$ & $\begin{array}{r}94 \\
195 \\
21 \\
43 \\
20 \\
5\end{array}$ & $\begin{array}{r}-0.07 \\
-0.13 \\
-0.05 \\
0.41 \\
0.67 \\
0.44\end{array}$ & $\begin{array}{r}0.80 \\
(4)\end{array}$ \\
\hline $\begin{array}{l}\text { 就 } \\
\text { 寝 } \\
\text { 時 } \\
\text { 刻 }\end{array}$ & $\begin{array}{l}1 \\
2 \\
3 \\
4 \\
5\end{array}$ & $\begin{array}{r}27 \\
140 \\
230 \\
32 \\
9\end{array}$ & $\begin{array}{r}0.12 \\
0.22 \\
-0.09 \\
-0.39 \\
-0.21\end{array}$ & $\begin{array}{r}0.51 \\
(5)\end{array}$ & $\begin{array}{r}22 \\
98 \\
220 \\
34 \\
4\end{array}$ & $\begin{array}{r}0.30 \\
0.18 \\
-0.12 \\
0.23 \\
-1.36\end{array}$ & $\begin{array}{c}1.66 \\
(2)\end{array}$ \\
\hline 距 & $\begin{array}{l}1 \\
2 \\
3 \\
4\end{array}$ & $\begin{array}{r}128 \\
147 \\
94 \\
69\end{array}$ & $\begin{array}{r}0.88 \\
0.06 \\
-0.71 \\
-0.80\end{array}$ & $\begin{array}{c}1.68 \\
(1)\end{array}$ & $\begin{array}{r}101 \\
106 \\
108 \\
63\end{array}$ & $\begin{array}{r}1.00 \\
0.10 \\
-0.57 \\
-0.81\end{array}$ & $\begin{array}{r}1.81 \\
(1)\end{array}$ \\
\hline \multicolumn{2}{|c|}{ 相関比 } & \multicolumn{3}{|c|}{0.67} & \multicolumn{3}{|c|}{0.61} \\
\hline
\end{tabular}

II類 ${ }^{8}$ による分析を地区別に行った.

(1) 鉄道からの距離, (2) 鉄道の見通し, (3) 生活パター ン, (4) 就寝時刻, (5) 年齢, (6) 居住歷, (7) 家の形態 この分析結果の一例として, 騒音に関する地区 1 と 2 の結果を示したのが 表一2 であり, 表一3 には分析の際 のカテゴリーの内容を示した.

数量化理論 II類は外的基準を説明変数で判別するもの であるが，その寄与の程度を本研究ではレンジを用いて 判断した. レンジの下につけた数字はレンジの大きさの 順位であり，これは諸要因の説明力の強さの順位にあた る.

以上の分析の結果, 騷音, 振動, 粉塵, 電波障害の各 因子では最も説明力が強いものが「鉄道からの距離」で あり, 他の要因に比べ安定している. 次に続くものが, 騒音では「鉄道の見通し」, 振動では「家の形態」であ り，定性的な判断でもうなずけるものがある.

一方，地区分断，景観に関しては卓越した説明力をも つ要因は見当たらず，相関比も前述の 4 項目に比べ小さ い. 地区分断，景観ともに「居住歴」「年齢」の説明力 が比較的強く，これらの項目に対する評価は地域の変化 のありさまを反映しているのではないかと思われる。一 般に説明力の弱い要因としては,「生活パターン」「就寝 時刻」が挙げられ，各項目に対する評価は個人的な行 動，立場には無関係で，住居の立地などの物理的条件が 大きく関与すると思われる.

次に地区別にみると，地区 5 において「家の形態」が 強い説明力があるように思える．本研究では地区を鉄道

表-4 2 つの要因による騒音被害の要因分析

\begin{tabular}{|c|c|c|c|c|c|c|c|}
\hline \multirow{2}{*}{$\begin{array}{l}\text { 要 } \\
\text { 因 }\end{array}$} & \multirow{2}{*}{$\begin{array}{l}\text { 力 } \\
\text { テ } \\
\vec{z} \\
\text { J } \\
1\end{array}$} & \multicolumn{3}{|c|}{ 地 区 1} & \multicolumn{3}{|c|}{ 地 $\quad$ 区 2} \\
\hline & & サンブ & $\begin{array}{l}\text { カテゴリー } \\
\text { スコア゙ }\end{array}$ & レンシ & $\begin{array}{l}\text { サンプ } \\
\text { ル数 }\end{array}$ & $\begin{array}{l}\text { カテゴリー } \\
\text { スコア゙ }\end{array}$ & レンジ \\
\hline $\begin{array}{l}\text { 見 } \\
\text { 通 } \\
\text { L }\end{array}$ & $\begin{array}{l}1 \\
2 \\
3 \\
4 \\
5\end{array}$ & $\begin{array}{r}154 \\
72 \\
80 \\
90 \\
42\end{array}$ & $\begin{array}{r}-0.27 \\
-0.31 \\
0.44 \\
0.12 \\
0.43\end{array}$ & 0.74 & $\begin{array}{r}142 \\
93 \\
41 \\
75 \\
27\end{array}$ & $\begin{array}{r}-0.48 \\
0.20 \\
0.23 \\
0.29 \\
0.70\end{array}$ & 1.18 \\
\hline 距 & $\begin{array}{l}1 \\
2 \\
3 \\
4\end{array}$ & $\begin{array}{r}128 \\
147 \\
94 \\
69\end{array}$ & $\begin{array}{r}-1.02 \\
-0.11 \\
0.74 \\
1.13\end{array}$ & 2.15 & $\begin{array}{r}101 \\
106 \\
108 \\
63\end{array}$ & $\begin{array}{r}-1.14 \\
-0.02 \\
0.63 \\
0.78\end{array}$ & 1.92 \\
\hline \multicolumn{2}{|c|}{ 相関比 } & \multicolumn{3}{|c|}{0.62} & \multicolumn{3}{|c|}{0.54} \\
\hline
\end{tabular}


の構造により平面地区・盛土地区に分け，また，鉄道と 道路の並行している複合地区に分類したが，これらの地 区によるばらつきはないといってもよいであろう。

表一2 は騒音の被害の説明要因のうち,「鉄道からの 距離」「鉄道の見通し」が強い説明力をむつことを示し ている. そこで，この 2 つを騒音の説明要因にとり分析 してみた. その結果の一部を 表一4 に示す.この結果を 表一2 と比較してみると相関比は $0.05 \sim 0.07$ だけ小さ くなるが，2つの要因でも十分説明し得ることを示して いる.

\section{（3）環境影響評価項目の被害率の距離減衰}

前節での数量化II 類による各評価項目の要因分析によ り，被害意識はいくつかの要因によって説明できること がわかった. 特に, 「鉄道からの距離」は大きなファク ターであり，卓越した説明力をもつといえる．そこで, 被害実態を鉄道からの距離別に分析するために調査対象 地区のゾーニングを行った. そのゾーニングは鉄道軌道 に平行に $20 \mathrm{~m}$ 幅で分割した. そして、ゾーンごとに各 評価項目の被害率（アンケート調査で「いつも感じる」 「しばしば感じる」「時々感じる」と答えた人の全数に対 する百分率）を計算した。なお，「日照・通風の障害」 「子供の線路侵入に対する不安」の両因子は被害率む低 く, サンプル数も少ないので分析からはずした.

これによると, 騒音, 振動, 電波障害, 事故の不安に 対する被害率は高く，景観，プライバシーの侵害の被害 率は比較的低い。また, 当然のことながら騒音, 振動, 電波障害, 粉塵の被害率は距離が遠くなるほど減少して いるが，事故に対する不安，地区分断の両項目は距離に よらずほぼ一定となっている.

地区別には盛土地区では騒音, 電波障害の被害がやや 遠くのゾーンまで及んでいる。これは騒音については音 波の伝播において，発生源が高い方が遠くまで影響を及 ぼすからであり，軌道構造物の高い方が電波を遮りやす いためであろうと思われる. しかし, 顕著な差はなく, 本研究で対象とした地区間では各評価項目の被害意識に ほとんど差がないといえる。

\section{（4）鉄道騷音の評価指標}

環境影響評価項目の中で，予測とその評価に関する研 究が最も進んでいるのは騒音である. 道路交通騒音の予 測法については 1975 年に日本音響学会より提案された いわゆる新音響学会式 9 があり，また，鉄道騒音に関し ても新幹線騷音はピークレベルで評価することになって いる. しかし，在来線については前述のように，今なお 評価方法が定まっていないので，本研究では種々の角度 から在来線鉄道の評価指標を検討してみた。
本研究で行った騒音実測は，鉄道から $10 \mathrm{~m}, 20 \mathrm{~m}, 40$ $\mathrm{m}, 80 \mathrm{~m}$ の距離において行ったものであり，これに対応 させて各実測地点前後 $10 \mathrm{~m}$ 内の住民の被害率を求め, これをその地点の被害率として，それと各種の騒音評価 指標との関係を分析した.評価指標としては,ピークレ心゙ ル $(\mathrm{PL}), 65 \mathrm{~dB}(\mathrm{~A}), 70 \mathrm{~dB}(\mathrm{~A})$ 以上の継続時間，また新 しく次式で表わされるいわば総騒音量の 4 つを用いた.

総騒音量 $=(\mathrm{PL}-65 \mathrm{~dB}(\mathrm{~A})) \times 65 \mathrm{~dB}(\mathrm{~A})$ の

$$
\text { 継続時間 } \div 2
$$

この総騒音量は $65 \mathrm{~dB}(\mathrm{~A})$ 以上の騒音值を時閒に関し て積分したものでここでは式（1）を用いて三角形に近 似したものである.本研究でこれらの指標を用いたのは， $\mathrm{PL}$ は環境庁の指針であること， $65 \mathrm{~dB}(\mathrm{~A})$ 以上の継続 時間は実測に際して読み取りやすいこと，70 dB(A) 以 上の継続時間は新幹線の環境基準であること，総騒音量 はPL または継続時間だけで評価したのでは不十分とい う可能性があると考えたこと，などがその理由である.

これらの評価指標と被害率の関係について 1〜8 地区 全地区まとめて回帰分析を行った結果，その相関係数は $\mathrm{PL}$ が $0.75,65 \mathrm{~dB}(\mathrm{~A})$ 以上の継続時間が $0.57,70 \mathrm{~dB}$ (A) 以上の継続時間が 0.39 ，そして総騒音量 0.65 とな り，すべて $1 \%$ 有意であった. PL について示したのが 図一4である. こ れより，PL が最 も被害率との相関 が高く，かつ，被 害率と PL が線形 関係とみなしてよ いと思われるの で, 本研究では以 下の分析において は，この PL を在 来線鉄道騒音の評

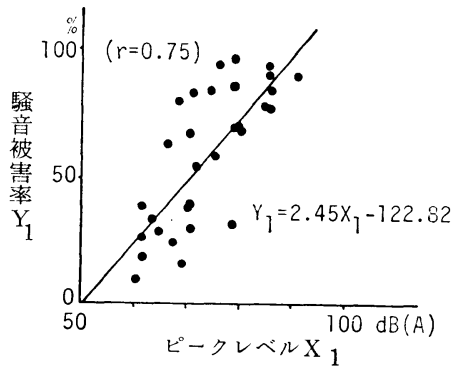

図-4 ピークレベル-騒音被害率の 回帰直線
価指標として取り扱うこととする．なお，ここでは騒音 についてのみ分析を行ったが，他の評価項目についても 物理的な評価指標の整備が望まれる.

\section{4. 鉄道沿線における環境影響の総合評価法 の比較}

\section{（1）従来の研究と本研究の方法}

現在まで鉄道沿線を対象とした環境総合評価の研究は ほとんどなく，他の施設計画についての研究を参考にせ ざるを得ない，本研究に関連のある従来の研究としては 表一5 に示すようなものがある. 一般に従来の研究は次 の3つのステップより成り，これらの研究の違いはこの 


\section{表一5 従来の環境総合評価手法}

\begin{tabular}{|c|c|c|c|c|}
\hline 評価手法 & 開発者・年代 & 評価主体 & 方 & 適用例 \\
\hline Overlay 法 & I.L. $\underset{1969}{\text { McHarg }}$ & 計画者 & $\begin{array}{l}\text { 環境項目の影響度を図示し, } \\
\text { 視賞的に総合評価す。 }\end{array}$ & 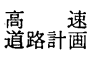 \\
\hline Matrix 法 & $\begin{array}{l}\text { L.B. Leopold } \\
\text { ほ大, } 3 \text { 名 } \\
1971\end{array}$ & 計画者 & 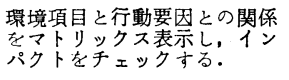 & 建設計画 \\
\hline 評価関数法 & $\begin{array}{c}\text { N. Dee ほ } \text { 活 } 5 \text { 名 } \\
1973\end{array}$ & 専門家 & 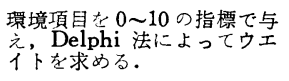 & $\begin{array}{l}\text { 水瓷源 } \\
\text { 開発計画 }\end{array}$ \\
\hline $\begin{array}{l}\text { 国土開発技 } \\
\text { 夕ーの究せン法 }\end{array}$ & $\begin{array}{c}\text { 国土開発 } \\
1974 \\
1974\end{array}$ & 専門家 & 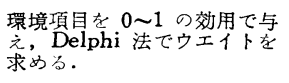 & 道路計画 \\
\hline $\begin{array}{l}\text { 多恋量解析法 } \\
\text { 方法 }\end{array}$ & $\begin{array}{l}\text { 稻村 } \\
1975\end{array}$ & 住 民 & 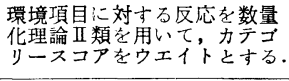 & 港湾計画” \\
\hline 䄇会心理学的 & 河上・青島・片平 & 住 民 & 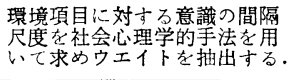 & 道路計画 \\
\hline
\end{tabular}

3 点の違いによるものと考えられる. (1) 各環境影響評 価項目の評価値はどのような 尺度をとるか。（2) 環境に 対する評価主体をどこに置くか. (3) 各評価項目の重要 度（ウエイト）をどのように算出するか。

本研究では，鉄道沿線の環境に対する評価は沿線住民 が行うものとし，住民意識調查のデータにより，沿線住 民の平均的な価值観, 効用曲線等を抽出し, ウエイトゔ けを行おうというものである．住民を評価主体に設定し た場合，そのウエイトゔけの方法は住民意識調査から多 変量解析法, 社会心理学的手法を用いてウエイトを得る のが一般的である.

多変量解析法を利用するものには重回帰分析, 数量化 理論I類，主成分分析等による方法がある.これらの多 くは個々の評価項目の不満度, 被害度 (不効用) を独立 変数とし, 環境全体への不満度, 被害度 (不効用) を従 属变数として解析するもので, 重回帰分析では偏回帰係 数, 数量化理論II類ではカテゴリースコアまたはレン ジ，主成分分析では因子負荷量を相対的ウエイトの值と している.

これらの方法は，簡明であるが，住民の意識をそのま ま計量化しているため, 住民のおかれている環境の影響 の大きさと総合評価に占める重要度とが混合した值とな っていて, その值をウエイトとした場合, 環境実態を強 く反映したものとなり, 他地区へ適用できるかどうかが 疑問である. 一方, 社会心理学の手法を用いた研究に は, 一対比較法, 順位法などがあるが, 一対比較法では いわゆる「3すくみ」の状態の処理をどうするかが疑問 であり，出てきた結果は間隔尺度であるのでそのままウ エイトには用いられない。

著者らの方法は，環境実態の影響を除いた各評価項目 のウエイトを求めるために, 上述の社会心理学の順位法 を用いて得た心理尺度上の距離 $\left({ }_{k} C_{i j}\right)$ を次式 ${ }^{10)}$ よう に説明し, 回帰分析によりウエイト $\left(W_{i}, W_{j}\right)$ を求め
るものである.

$$
{ }_{k} C_{i j}=W_{i} \cdot{ }_{k} U_{i}-W_{j} \cdot{ }_{k} U_{j}
$$

ここに, ${ }_{k} C_{i j}: k$ ゾーンに扔ける評価項目 $i, j$ の心理尺度上の距離, $W_{i}, W_{j}$ : 評価項目 $i, j$ の総合評価における相対的ウエイト, ${ }_{k} U_{i}$, ${ }_{k} U_{j}: k$ ゾーンに扔ける評価項目 $i, j$ の環境実 態の評価値， $k$ : 土地利用を考慮して，軌道に 平行および垂直な線で，対象地区を評価值がそ のゾーン内でほぼ一様になるょうに分割したと きの $k$ 番目のゾーン.

この式は住民が環境影響評価項目 $i$ と $j$ の 実態とそれらの重要さを総合判断して，その心 理尺度上の距離が決定されると考えて導かれ たものである.

\section{（2）各評価項目の総合評価におけるウェイトづけの 方法の比較}

住民意識調査に扔いては, 前述の社会心理学を忍用し た手法を用いてウェイトを算出できるように，表一6に 示すような騒音, 振動その他の各評価項目に対する対策 要望順位を上位 5 位まで質問した. この質問に対する回 答に順位法の分析法を適用し, Thurstone の距離尺度を 導入して各項目に対する間隔尺度を求めた. さらに, 式 （2）における環境実態の評価值 $\left({ }_{k} U_{i},{ }_{k} U_{j}\right)$ として各評 価項目の被害率を用いた. これは，被害率を各個人の 評価項目に対する不効用を表わす $(0 \sim 1)$ の指標とみな していることによる.

表一6 社会心理学的手法によるウエイト

\begin{tabular}{|c|c|c|c|c|c|c|}
\hline 区 & 騒 音 & 動 & 電波障害 & 車故安 & 地区分断 & 粉 \\
\hline 1 & 0.24 & 0.20 & 0.12 & 0.19 & 0.13 & 0.12 \\
\hline 2 & 0.34 & 0.20 & 0.13 & 0.21 & 0.07 & 0.05 \\
\hline 5 & 0.18 & 0.20 & 0.15 & 0.15 & 0.14 & 0.18 \\
\hline 6 & 0.20 & 0.18 & 0.11 & 0.15 & 0.10 & 0.26 \\
\hline 7 & 0.21 & 0.15 & 0.22 & 0.14 & 0.18 & 0.10 \\
\hline 8 & 0.19 & 0.23 & 0.21 & 0.11 & 0.20 & 0.06 \\
\hline 平均 & 0.23 & 0.19 & 0.16 & 0.16 & 0.14 & 0.13 \\
\hline 変動係数 & 0.25 & 0.14 & 0.29 & 0.22 & 0.35 & 0.64 \\
\hline
\end{tabular}

これらのデータを式 (2) に代入し, 重回帰分析を行い ウエイト $\left(W_{i}, W_{j}\right)$ を求めた. いま, $n$ 個の評価項目 についてこの分析をすると, ${ }_{n} C_{2}$ 個の $\left(W_{i}, W_{j}\right)$ が得 られる. もし, 式 (2) の仮定がすべて満足されれば, す べての項目のウエイトが一意に決まるはずであるが，通 常は人間の意識のあいまいさを反映して一意には決まら ない。 また, 項目間に相関性があれば, 偏相関係数 (こ こではウエイト）の信頼性が低くなる. そこで本研究で は，信頼性の低いウエイトをはずして，信頼性の高いウ エイトのうち 1 つを基準としてその相対的ウエイトを求 
表一7 数国化理論 II 類によるウエイト

\begin{tabular}{|c|c|c|c|c|c|c|c|}
\hline 区 & 騒 音 & 振 動 & $\begin{array}{l}\text { 霎 } \\
\text { 害 }\end{array}$ & $\begin{array}{l}\text { 事故の } \\
\text { 安 }\end{array}$ & 坋 & 粉 塺 & 相関比 \\
\hline 1 & 0.50 & 0.05 & 0.03 & 0.21 & 0.10 & 0.11 & 0.86 \\
\hline 2 & 0.12 & 0.22 & 0.19 & 0.17 & 0.03 & 0.27 & 0.88 \\
\hline 5 & 0.33 & 0.13 & 0.14 & 0.26 & 0.10 & 0.04 & 0.86 \\
\hline 6 & 0.30 & 0.23 & 0.10 & 0.06 & 0.16 & 0.15 & 0.84 \\
\hline 7 & 0.33 & 0.36 & 0.12 & 0.07 & 0.05 & 0.07 & 0.82 \\
\hline 8 & 0.37 & 0.16 & 0.05 & 0.14 & 0.14 & 0.14 & 0.83 \\
\hline 平 均 & 0.33 & 0.19 & 0.11 & 0.15 & 0.10 & 0.13 & \\
\hline 変動係数 & 0.38 & 0.56 & 0.56 & 0.51 & 0.57 & 0.62 & \\
\hline
\end{tabular}

\section{表一8 重回州分析によるウェイト}

\begin{tabular}{|c|c|c|c|c|c|c|c|}
\hline 地 区 & 騒 音 & 振 動 & 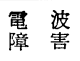 & $\begin{array}{l}\text { 事故の } \\
\text { 安 }\end{array}$ & 地 分 & 粉 塺 & $\begin{array}{l}\text { 重相閔 } \\
\text { 数 }\end{array}$ \\
\hline 1 & 0.49 & 0.17 & $(0.00)$ & 0.27 & 0.07 & $(0.00)$ & 0.83 \\
\hline 2 & 0.17 & 0.23 & 0.18 & 0.20 & $(0.05)$ & 0.17 & 0.80 \\
\hline 5 & 0.39 & $(0.07)$ & 0.13 & 0.26 & 0.12 & $(0.03)$ & 0.85 \\
\hline 6 & 0.36 & 0.20 & 0.10 & $(0.04)$ & 0.13 & 0.17 & 0.81 \\
\hline 7 & 0.41 & 0.19 & $(0.06)$ & 0.20 & $(0.04)$ & 0.10 & 0.72 \\
\hline 8 & 0.35 & 0.14 & $(0.00)$ & 0.18 & 0.13 & 0.20 & 0.78 \\
\hline 平 均 & 0.36 & 0.17 & 0.08 & 0.19 & 0.09 & 0.11 & \\
\hline 变動係数 & 0.30 & 0.32 & 0.92 & 0.47 & 0.44 & 0.75 & \\
\hline
\end{tabular}

め, 平均した. この結果を $\sum_{i=1}^{n} W_{i}=1$ となるように地区 ごとに求めたのが 表一6である．また，本研究ではこの 社会心理学的手法の妥当性を検証するために, 重回帰分 析と数量化理論I類によってもウエイトを求めた. 重回 帰分析は住民意識調査での環境被害意識に対する質問の 5 段階の不満度のカテゴリーをそのまま比例尺度とみな して, 各評価項目に対する被害度を独立変数とし環境全 体に対する不満度を従属変数として分析を行った. 数量 化理論類では，同様のカテゴリーを用い各評価項目に 対する被害度を説明変数とし，環境全体に対する不満度 を外的基準として分析を行った. ウエイトはそれぞれ偏 回帰係数, レンジを用い, やはり $\sum_{i=1}^{n} W_{i}=1$ となるよう に基準化し，表一7, 8 に地区別に示した. この表一7,8 では相関比，重相関係数をその信頼性を表わす值として 併記したが，全地区において有意である。 また，表一8 で括弧を施したのはその係数が $5 \%$ 有意にも入らないも のであり，景観，プライバシーの侵害はすべての地区で 有意でなかったので表からはずした．また，盛土地区 （地区 3，4）では事故の不安に対する意識が他地区と異 なると思われるので分析からはずした． 表一6〜8 では 各項目に対するウエイトの平均值, 変動係数も示した が，変動係数は社会心理学的手法が最も小さいことがわ かる. これは各評価項目に対する重要度が地区によって あまり変わらないことを示しており，この手法によって 環境実態とウエイトがより適切に分離されたと考えられ る. 本研究では以上の 3 手法の適合性を検討するため に, 各手法の平均のウエイトを用い, ゾーン $k$ の総合
評価值 $\left(F_{k}\right)$ を次式のように加重総和として求めた.

$$
F_{k}=\sum_{i}^{n} W_{i} \cdot{ }_{k} U_{i} \cdot
$$

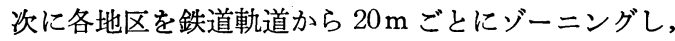
1 ゾーンの平均サンプル数を 50 人程度として，上記の $F_{k}$ とアンケート調查結果より得られる環境全体に対す る不満率とを比較した. いま，もし予測值 $F_{k}$ が妥当な ら環境全体に対する $k$ ゾーンの不満率との相関が高い はずである. その比較分析の結果, 社会心理学的手法, 重回帰分析による方法, 数量化理論類による方法のい ずれにおいても，予測值と実績值の相関係数は 0.86 前 後で $1 \%$ 有意であり, なかでは社会心理学的手法がわず かに他の方法より よい相関を示して いる.これについ ての結果を 図一5 に示す.

3 手法を比較し た場合，環境影響 評価の予測精度は あまり変わらなか ったが, ウエイト の值の地区による 変動が小さいこと

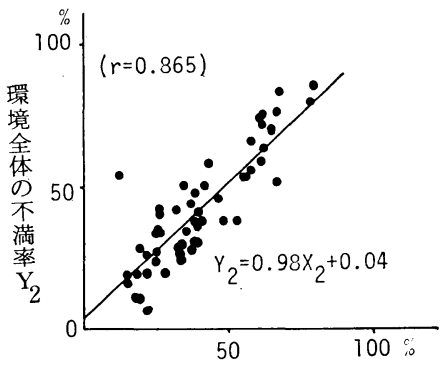

環境総合評価值 $\mathrm{X}_{2}$

図一5 社会心理学的手法の 適合性の検証
を考慮すると, 社会心理学的手法が最もよい手法である といえる. また，ここではウエイトの平均値をとって全 地区のウエイトとしたが，さらに各地区を 1 つのジーン とみなして，社会心理学的手法を用いることむ可能で, この值を代表的個人の考えるウエイトとすれば予測精度 はもっと上がるであろう。

\section{（3）代表的環境影響評価項目の抽出}

前節では環境総合評価の手法を述べてきたが，各評価 項目のウエイトづけには社会心理学的手法が最もよいと いうことがわかった. しかし，予測精度自体は各手法に よる差は顕著ではない.ここではこれを考察するととも に，視点を変えてより少ない評価項目で環境総合評価を 行うことを検討する．つまり，予測精度がそれほど変わ らないのは評価項目間の相関性が影響しているためでは ないかと思われる．そして，この相関性を利用すればよ り少ない項目での環境の総合評価が可能になる.

本研究でも環境総合評価は各項目の評価の信頼性から $6 つ の$ 評価項目で行った. また，現在の鉄道計画に扔け る環境評価システムにおいて，いまだに各評価項目の予 測手法が確立していないことを考虑すると，より少ない 項目で環境総合評価値を与えることは，概略の指針を得 る際には現実的であるといってよい。

そこで，取り上げる項目の削減に対する一つの基準と 
して，相関性の高い項目群は 1 つの項目と考えることに する. 項目間の相関性を知るための手法としては, ピア ソンの相関係数，クラマーのコンティンジェンシー係 数, 因子分析による方法などがあるが，本研究ではピア ソンの相関係数, クラマーのコンティンジェンシー係数 を地区 8 において算出した. この結果, 騒音と振動, 粉 塵と日照, 通風の障害とプライバシーの侵害の間に高い 相関があることがわかった。

しかし，相関が高いからといって，たとえば騷音と振 動の被害実態が大きく違う場合（防音壁を設置してある 場合など）など同一視してよいかということに疑問があ る. また，一つの基準としてウエイトの信頼性から項目 数を削減することも可能であるが，これではそのたびご とに環境総合評価值を求める評価項目の数が変わってく る可能性がある.

そこで，もう一つの基準を付け加えて，予測がある程 度可能な項目のみを用いるということも考えられる．現 状では騒音だけが可能とみてよい，そこで騒音の被害意 識のデータを用い て，環境全体の不 満率との関係を回 帰分析した結果を 図一6 に示す.こ れをみると図一5 に比べて，相関倸 数はやや落ちてい るが，有意性にお いて顕著な差はな い.

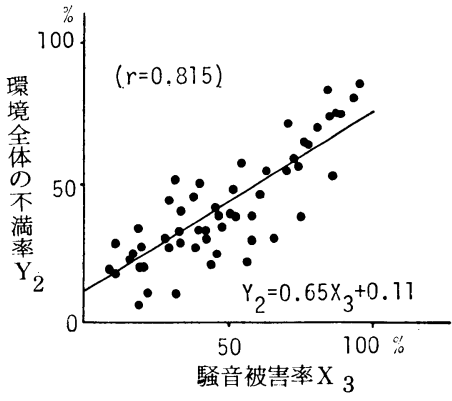

\section{したがって，環}

\section{図一6 騒音被害率-環境全体の} 不㴖率の回带直線

境総合評価をより少ない評価項目で表わすことは可能だ といえる. しかし，この方法は分析上の簡便法であるこ とには間違いがなく，また，はたしてこれで住民のコン センサスを得られるか疑問である，ところが現実を考虑 すると，何らかの形で概略的にでも環境総合評価值を算 出する必要性は高い，また，すべての項目を網羅するこ とは非常に困難な場合が多い，そこで，予測の可能性の ある項目を用い，研究の蓄積に従い，上り網羅的な環境 総合值を求める方向にもっていくという方法も検討しな くてはならない.

\section{（4）計画代替案の環境総合評価}

前節まで環境総合評価値 $\left(F_{k}\right)$ を求める方法を考察し てきた. しかし， $F_{k}$ を求めるだけでは鉄道計画の代替 案を評価することはできない。この節では，この $F_{k}$ を 現実の鉄道計画に用いるために考慮すべきことについて 述べる.
本来, $F_{k}$ は $k$ ゾーンの環境総合評価値であるため, 鉄道路線の代替案の環境評価のような全路線を考慮する 場合には，何らかの新しい操作をしなくてはならない， 1.の 図一2 で示したように住民がその沿線環境を評価 するものとすれば，沿線住民の人口分布が問題となるの は当然である.つまり， $k$ ゾーンの環境総合評価值にそ のゾーンに住んでいる人口の重みを考虑しなければなら ない.

しかし，実際には沿線住民をどの範囲のものにするか は分析を効率よく行ううえで重要であり，本研究ではこ の範囲を被影響面積という概念を用いて定義した. 被影 響面積とは，各環境影響評価項目がその被害を及ぼす範 囲のことであり，これは鉄道からの距離で計測できる.

本研究では，各環境被害の被害率が $20 \%$ 以下になる 地点までの距離を, この被影響距離としてその距離を割 り出した.この結果を表一9に示す.これをみると地区 によるばらつきがあるが，項目別の影響範囲をみつける ことはできる.これらの最大值を目安に被影響距離を決

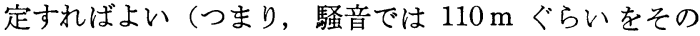
值とすればよいと思われる)。なお，被害率が $20 \%$ の距 離を被影響距離としたのは，20\% 前後から 被害率が横 ばいになるものが多く，住民の反応の信頼性が悪くなる こと，また被害も小さくなることを考えたからで，絶対 的な基準ではない。

次に，環境影響の程度を考慮する必要がある，たとえ ば人口が同じでもそのゾーンが農地と住居地ではその影 響の程度が違うというのが，土地利用計画，または環境 基準の考え方である.

建設省土木研究所の 報告 ${ }^{2)} ゙$ は，都市計画の用途地域 別建物用途制限個数等を参考にして，土地利用別のウエ イトを表一10 のように設定している。この值は人口を も考虑しているため，多少土地利用による格差が大きい

\section{表一9 各環境因子の被影䍌距離}

\begin{tabular}{|c|c|c|c|c|c|c|}
\hline 地区 & 騒 音 & 振 動 & 電波障害 & 粉 塵 & 景 観 & $\begin{array}{l}\text { プライバン } \\
\text { ーの侵害 }\end{array}$ \\
\hline 1 & 50 & 46 & 40 & 27 & 21 & 20 \\
\hline 2 & 79 & 105 & 49 & 28 & 26 & 20 \\
\hline 3 & 84 & 78 & 68 & 22 & - & 29 \\
\hline 4 & 92 & - & 76 & 27 & 30 & 22 \\
\hline 5 & 78 & 57 & - & 27 & 19 & 22 \\
\hline 6 & 100 & 78 & 73 & 56 & 30 & 28 \\
\hline 7 & 100 & 46 & 100 & 28 & 19 & 26 \\
\hline 8 & 110 & 84 & 102 & 28 & 26 & 33 \\
\hline
\end{tabular}

表一10 土地利用によって決まるウェイト

\begin{tabular}{|c|c|c|c|c|c|}
\hline 土地 利 用 & 1 種住専 & 2 種住専 & 住居地域 & 住宅地 & 近篻商業 \\
\hline ウエ 1 ト & 0.7 & 1.0 & 0.7 & 0.7 & 0.5 \\
\hline 土地利 用 & 商業地域 & 準工業地域 & 工業地域 & 工専地域 & 農 \\
\hline ウェ & 0.5 & 0.5 & 0.1 & 0.1 & 0.1 \\
\hline
\end{tabular}


と考えられる.

以上を総合して，鉄道路線代替案の評価のための環境 総合影響值 $(S)$ は次式のように算出できる. なお， い くつかの地区を含んだ広域的な分析には，地区ごとに得 られた值を加算する必要がある.

$$
S=\sum_{k=1}^{m} F_{k} \cdot P_{k} \cdot L_{k}
$$

ここに, $P_{k}:$ ゾーン $k$ における人口ポテンシャルによ って決まるウエイト， $L_{k}:$ ゾーン $k$ における土地利用 によって決まるウエイト。

\section{5. 鉄道計画の総合評価法に関する試案}

\section{（1）計画の総合評価方法}

鉄道計画のみならず，一般に土木施設計画に対する総 合評価の方法は, 費用便益分析等, 多くの研究がなされ ているにもかかわらず，いまだ十分に確立したとはいえ ない現状である.今日の鉄道計画においても異なる性質 の複数の目的をもつために，1つの共通な評価尺度（ま たは価值観）で，各目的を定量化することが困難な場合 が多い.しかし，複数の代替案から最良の代替案を選ぶ ことは, 必要かつ切実な問題である.

本研究でいうところの計画の総合評価とは，最初に述 ベたように独立した各種の評価システム（利便性, 経済 性，環境影響）を総合し評価することを指し，環境評価 システムはこの総合評価が可能な指標をもたなくてはな らない。総合評価手法の代表例を表一11 ${ }^{11)}$ に示す.

これらの手法を大きく 2 つに分けるとすると，異なる 次元の尺度を統一した評価尺度に変換するか否かである ように思われる，統一した評価尺度とは，現在ではその ほとんどが貨幣タームか効用である．また，異なる尺度 で評価する方法に多目的計画法 ${ }^{12)}{ }^{13)}$ などが 最近開発さ れているが，まだ十分に理論が完成されていない.

評価尺度に貨幣タームを用いる手法は費用便益分析に

\section{表一11 従来の䋛合評価手法}

\begin{tabular}{|c|c|c|c|}
\hline 手 & 評価項目 & 評 価 尺度 & 評 価 \\
\hline $\begin{array}{l}\text { 費用便益 } \\
\text { 析 }\end{array}$ & 直接効果 & $\begin{array}{l}\text { インパクトの大 } \\
\text { きさを貨幣ター } \\
\text { ムで評価する. }\end{array}$ & $\begin{array}{l}\text { 費用便益差(比)を最大 (最 } \\
\text { 小) にする. }\end{array}$ \\
\hline $\begin{array}{l}\text { バランス. } \\
\text { シート法 }\end{array}$ & すべての項 & 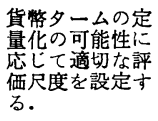 & $\begin{array}{l}\text { 環境・社会面の評価を制約 } \\
\text { として費用便益分析を角い } \\
\text { る. }\end{array}$ \\
\hline $\begin{array}{l}\text { 費用有効度 } \\
\text { 分 }\end{array}$ & $\begin{array}{l}\text { 定量的に計 } \\
\text { 湔できる項 } \\
\text { 目 }\end{array}$ & $\begin{array}{l}\text { 項目ごとに評価 } \\
\text { 尺度を設 定す } \\
\text { る. }\end{array}$ & $\begin{array}{l}\text { (1) 有効度一定 - 費用最小 } \\
\text { (2) 費角二定・有効度大 } \\
\text { (3) 有效度・費用比最大 }\end{array}$ \\
\hline 効用関数法 & $\begin{array}{l}\text { 心理的な項 } \\
\text { 貝も念め } \\
\text { 定量的に計 } \\
\text { 荊できる項 } \\
\text { 自 }\end{array}$ & $\begin{array}{l}\text { インパクトをで } \\
\text { きるかきり例 } \\
\text { 尺度で評価す } \\
\text { る. }\end{array}$ & $\begin{array}{l}\text { 総合的な評価值を求め, こ } \\
\text { の大きさによって選択を行 } \\
5 .\end{array}$ \\
\hline
\end{tabular}

代表される．この手法は「代替案の比較が容易である」 「比較的マク口な分析でも納得性がある」などの利点を もつが，「社会的費用など計測の困難な項目がある」「便 益の分配という公平性の基準に久けており，複数の目的 間の調整が困難である」などの欠点がある ${ }^{11}$.

一方, 効用を評価尺度とする効用関数法は, 評価情報 の総合化, 項目間のトレード・オフ関係の把握の困難性 などの問題を 解決しようというものであり，「価値観の 異なるグループ の取扱いが容易」「インパクトおよび評 価の不確実性の考慮が 容易」などの利点をもつが，「そ の計測について 膨大な分析作業を必要とする」「人間の 意識構造のあいまいさを考虑していない」などの欠点が ある ${ }^{11)}$ 。これらの手法はそれぞれ一長一短があり，現在 では卓越した手法はなく，それぞれの状況に応じて，計 画にとって最適な手法を用いなくてはならない，

本研究の環境評価システムは, いわば不満度・被害度 といら不効用を用いた効用関数法であり，環境総合影響 值は不効用の加算という形で算出された. さらに，鉄道 計画の代替案評価のためには，環境のみでなく利便性， 経済性などを総合的に考虑しなくてはならない，本分析 では，計画の総合評価にも同様の方法を用いることとす るが，経済性については別稿に譲るとして，ここでは， 環境と利便の総合的な評価の問題についてのみ，以下に 考察を加える.

\section{（2）環境と利便のトレード・オフ}

本分析では著者らによって 開発された方法 ${ }^{14)}$ 適用 し，トレード・オフの関係を考虑した総合評価值を求め ることとする．4．では環境総合評価值を算出したわけ であるが，これらと同様に他の評価項目群の総合評価值 が算出されたとすると，それらを総合評価した総合評価 值 $\left(T_{k}\right)$ は，一般的には，加法的効用関数を用いて次式 のように表わすことができる.

$$
T_{k}=\sum_{l=1}^{q}{ }_{l} W \cdot{ }_{l} F_{k}
$$

ここに, ${ }_{l} W: l$ 番目の評価項目群のウエイト, ${ }_{l} F_{k}: k$ ゾーンに抢ける $l$ 番目の評価項目群の評価値, $q$ : 評価 項目群の総数.

多くの場合, この ${ }_{l} F_{k}$ 間にはトレード・オフの関係 があり，負の相関性が強いので多変量解析によるウエイ トづけは困難であるが，前章で用いた社会心理学的手法 を用いることにより，トレード・オフを考慮した総合評 価值を求めることが可能であると考えられる.

この事例研究として, 本研究では, 利用者であり, か つ環境影響の被害者であるところの鉄道沿線住民の総合 評価における環境と利便のウエイトゔけについて分析す る. 本分析の主眼点は同一個人が異なった立場をあわせ 
もつときの調整点, 合意点のとり方に注目するところに ある. いま，鉄道沿線住民の総合評価值 $\left(T_{k}\right)$ は式 (5) を適用すれば次式のようになる。

$$
T_{k}={ }_{f} W \cdot F_{k}+{ }_{b} W \cdot B_{k} \cdot
$$

ここに, ${ }_{f} W,{ }_{b} W$ : 環境と利便に対するウエイト, $F_{k}$, $B_{k}: k$ ゾーンの環境と利便の総合評価值.

また

$$
\begin{aligned}
& F_{k}=\sum_{i=1}^{n}{ }^{f} W_{i}{ }_{k} U_{i} \\
& B_{k}=\sum_{i=1}^{m}{ }^{b} W_{i}{ }_{k}^{b} U_{i}
\end{aligned}
$$

ここに, ${ }_{k}^{f} U_{i}: k$ ゾーンの環境に関する評価項目 $i$ の不 効用, ${ }_{k}^{b} U_{i}: k$ ゾーンの利便に関する評価項目 $i$ の不効 用, ${ }^{f} W_{i},{ }^{b} W_{i}$ : 環境と利便に関する各評価項目 $i$ のそ れぞれの総合評価に占めるウエイト．

\section{（3）本研究で提案する方法の適用例}

本研究の住民意識調査では環境影響評価項目と同じく 鉄道の利便性の評価項目について不満度を 5 段階で質問 した. その評価項目は以下の 7 項目である.

(1) 駅までのアクセスの便, (2) 車内の混雑, (3) 下車駅 での乗り換え, (4) 終始発時刻, (5) 列車本数, (6) 費 用, (7) 所要時間

5 段階の不満度の質問のうち,「やや不満」「不満」と 答えた人の全数に対する割合を不満率とし，この不満率 を式 (8) の ${ }_{k}^{b} U_{i}$ として, ウエイトを前章と同様の $3 つ$ の手法を用いて求めた. 地区 7,8 についての結果が 表一12 である. ここでも各手法によってそのウエイト

\begin{tabular}{|c|c|c|c|c|c|c|c|}
\hline 地区 & 法 & 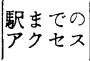 & $\begin{array}{ll}\text { 所 } & \text { 要 } \\
\text { 時 }\end{array}$ & $\begin{array}{l}\text { 車 内 } \\
\text { 湿 雑 }\end{array}$ & 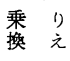 & 䅂始發 & 列 車 \\
\hline \multirow{3}{*}{7} & $\begin{array}{l}\text { 社会心理 } \\
\text { 学的法 }\end{array}$ & 0.17 & 0.24 & 0.22 & 0.15 & 0.15 & 0.07 \\
\hline & $\begin{array}{l}\text { 数量化理覦 } \\
\text { 類 }\end{array}$ & 0.34 & 0.20 & 0.18 & 0.11 & 0.12 & 0.05 \\
\hline & 重回帰分析 & 0.41 & 0.09 & 0.10 & 0.27 & 0.12 & $(0.01)$ \\
\hline \multirow{3}{*}{8} & $\begin{array}{l}\text { 社会心理 } \\
\text { 学法 }\end{array}$ & 0.30 & 0.18 & 0.18 & 0.18 & 0.06 & 0.10 \\
\hline & $\begin{array}{l}\text { 数量化理論 } \\
\text { 類 }\end{array}$ & 0.37 & 0.16 & 0.15 & 0.13 & 0.10 & 0.09 \\
\hline & 重回帰分析 & 0.44 & 0.15 & $(0.04)$ & 0.22 & $(-0.02)$ & 0.15 \\
\hline
\end{tabular}
が違うことがわかる.

\section{表一12＼cjkstart諸方法による利便性の因子のウエイト}

\begin{tabular}{|c|c|c|c|c|c|c|c|}
\hline 区 & $\begin{array}{l}\text { 駅までの } \\
ア ク セ ス ~\end{array}$ & $\begin{array}{l}\text { 車 内 } \\
\text { 混 雑 }\end{array}$ & 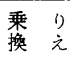 & $\begin{array}{l}\text { 終始發 } \\
\text { 時 }\end{array}$ & $\begin{array}{ll}\text { 烈 車 } \\
\text { 数 }\end{array}$ & 乺 賈 & $\begin{array}{ll}\text { 乺 要 } \\
\text { 時 間 }\end{array}$ \\
\hline 1 & 0.20 & 0.22 & 0.08 & 0.11 & 0.18 & 0.21 & - \\
\hline 2 & 0.04 & 0.15 & 0.13 & 0.26 & 0.32 & 0.10 & - \\
\hline 3 & 0.14 & 0.13 & 0.14 & 0.12 & 0.27 & 0.20 & - \\
\hline 4 & 0.14 & 0.16 & 0.11 & 0.11 & 0.30 & 0.18 & - \\
\hline 7 & 0.17 & 0.22 & 0.15 & 0.15 & 0.07 & - & 0.24 \\
\hline 8 & 0.30 & 0.18 & 0.18 & 0.06 & 0.10 & - & 0.18 \\
\hline 平 均 & 0.16 & 0.18 & 0.13 & 0.13 & 0.21 & 0.17 & 0.21 \\
\hline
\end{tabular}

表一13 社会心理学的手法による利便性の因子のウェイト

\begin{tabular}{|c|c|c|c|c|c|c|c|}
\hline 地 & 区 & 1 & 2 & 3 & 5 & 7 & 8 \\
\hline 環 & 境 & 0.45 & 0.43 & 0.46 & 0.68 & 0.64 & 0.59 \\
\hline 利 & 便 & 0.55 & 0.57 & 0.54 & 0.32 & 0.36 & 0.41 \\
\hline & 音 & - & - & - & - & 0.46 & - \\
\hline 所要時 & & - & - & - & - & 0.54 & - \\
\hline
\end{tabular}

表一14 総合評価指標のウエイト

また, 社会心理学的手法のみを用いて, 地区別にウエ イトを求めた結果を 表一13 に示す.これをみるとほと んど同程度のウエイトであり，卓越した因子がないこと に気つくくまた，地区によっての変動も大きく，地区 2 , 3,4 では列車本数が，地区 1,8 では駅までのアクセス が最もよく利便性の評価を説明している.これは地区ご との物理的な交通条件の違いが，利便性の意識に大きく 反映しているためと思われる.

次に, 式 (6) におけるウエイト ${ }_{f} W,{ }_{b} W$ を求めるた めに，やはり社会心理学的手法を用いた. $F_{k}$ の值とし て環境全体に対する不満率， $B_{k}$ の值として利便性全体 に対する不満率を用いた. また，Thurstone の距離尺度 は「交通の便利さの改善」か「沿線の環境対策」かとい う一対比較の質問によって求めた. 算出されたウエイト を表一14 に示す. 地区 4, 6 については, その值の信 頼性が低いために記入しなかった. また，地区7では $F_{k}$ の值として騒音の被害率を, $B_{k}$ の值として所要時 間の不満率をそれぞれ用いて求めたウエイトを併記し た.

さらにこれらの值の信頼性を検証するために，住民意 識調査で翼問した 鉄道に対する 総合評価（「満足」から 「不満」までの 5 段階による質問）の不満率を縦軸に, 式（6）における総合評価值 $\left(T_{k}\right)$ を横軸にとり, 地区 7 についてゾーンごとにその值を求めプロットした. ま た, 回帰分析を用いてその相関性を検討した結果を示し たのが図一7,8 で ある. なお,ここ で地区 7 のみ取 り上げたのは, 地 区ごとに利便の説 明変数が異なる, というデータ上の 制約による.した がって,ここでは 厳密法と簡便法と の比較に重点を置 くこととする.

図一7 は $F_{k}, B_{k}$ にそれぞれ環境, 利便性の不満率を 代入して求めた総

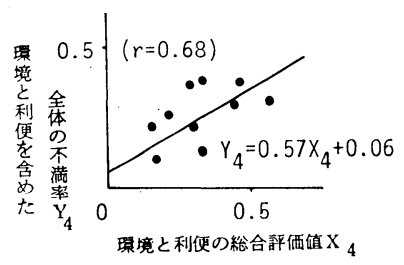

図一7環境と利便に関する総合 評価值の適合性の検証

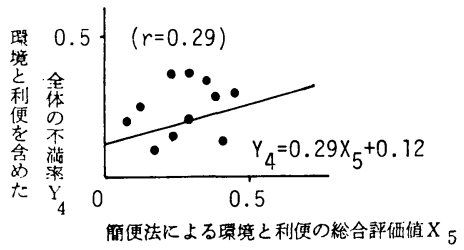

図一8 简便法による環境と利便に 関する紗合評価值の適合性 の検証 
合評価值の検証の結果（箃密法）である. また，図一8 は騒音の被害率と所要時間の不満率を $F_{k}, B_{k}$ に代入し たものであり，4. で考察した方法と同様に，より少な い因子でこの総合評価值が求まるかどうか（簡便法）の 検証である.なお，利便性の代表的評価項目として，所 要時間を用いたのは過去の研究例15)を参考にした.

この図をみると，いずれも相関係数が小さいことがわ かる.これはまったく性格の異なる因子間のトレード・ オフのために, ウエイトを計測しにくいことが原因であ ると考えられる. しかし，図一7の 0.68 といら相関係 数は有意水準には達している. 一方, 図一8 は仮定が多 すぎて精度が悪くなったと考えられる.このような総合 評価の場合, システムが 複雑化, 高次元化してくるた め，簡便法では問題があるように思われる.

以上，鉄道沿線住民の環境影響と利便性に関する総合 評価値を求める方法を提示した．同様の方法，および意 識調査を行うことで利用者の利便性と経済性に関する総 合評価值等を求めることも可能である.

\section{6. むすび}

鉄道沿線における環境影響評価の方法および，その方 法を鉄道計画の全体の評価システムの中にどのように組 み込むのかに関する方法論について, 種々の分野におい て研究が進められているが，いまだ開発の途上にあると いうのが現状であろう.本研究ではこのような課題に対 して, 部分的に不十分な点を残しながらも, 現状分析に 基づいてその体系化を試み，そして 2,3 の方法の提案を 行い，その実用的有用性について実証した. 今後は, 本 研究に対する大方の批判を迎ぎながら，提案した方法を さらに精緻なむのにしていかなければならない。また， 残された課題としては，一つには取り扱うべき環境影響 評価項目の範囲をどうするのかという問題であり, 本研 究では物理的な量として騒音のみを対象とし, 意識的な 量としては可能な限り広げて考えるという方法をとっ た. 今後, 各評価項目の物理量の予測手法の開発とその 評価に関する研究の進展に伴って, 対象の範囲を広げて いく必要があるう。ただし，際限なく広げるということ ではなく，技術的あるいは費用的制約のもとで，適正な 範囲というものが見出されなければならない。二つに
は，計画全体の評価システムの中に環境評価システムを どのように組み込むのかという問題であり，とりわけ経 済性の評価システムとの斉合である，そのための一つの 方法として，環境影響量の貨幣タームへの変換の問題が あるが，これについては，今後十分な解明が必要である と思われる。

最後に，査読者に多くの親切なご指摘をいただいたこ とを感謝いたします。

\section{参 考 文 献}

1）青島縮次郎：道路交通計画における環境評価システムに 関する研究, 名古屋大学学位論文, pp. 20 41, 1979.

2）森 寛昭・金安公造：道路計画に㧍ける環境影響の総合 評価に関する一手法, 土木計画学研究発表会講演集 1, pp. 156 159, 1979.

3）浅野俊樹：鉄道沿線地区の 環境影響評価に 関寸る研究， 名古屋大学修士論文, 1978 .

4）河上省吾・青島縮次郎・荻野 弘・渡辺健司：夜間の長 距離信号制御による騒音防止効果について, 交通工学, Vol. 13, No. 4, pp. 3 10, 1978.

5）国土開発技術研究センター: 環境アセスメント手法につ いて, 1974

6）松野三朗：アメリカ合衆国における環境アセスメント手 法の紹介, 第 8 回土木計画学講習会テキスト, pp. 25〜 44, 1975.

7）青島縮次郎・河上省吾・片平和夫：幹線道路周辺の環境 影響評価, 交通科学, Vol. 7, pp. 1 7, 1978.

8）林知己夫・村山孝喜：市場調査の計画と実際，日刊工業 新聞社, 1975.

9）石井聖光：道路交通騒音予測計算方法汇関する研究（そ の 1）一実用的な計算式について一，日本音響学会誌, Vol. 31, No. 8, pp. 507 517, 1975.

10）青島縮次郎・河上省吾・片平和夫：幹線街路周辺の環境 総合評価に打ける各因子の重みづけについて，土木学会 論文報告集, No. 263, pp. 97 106, 1977.

11）近畿地方建設局：総合評価手法に関する文献・凟料。 1978.

12）伏見多美雄・山口俊和：複数の目標をバランスよく達成 するための数理計画法, 経営科学, Vol. 19, No. 2, pp. $88 \sim 102$.

13）長尾義三・浅岡 顕・若井郁次郎 : 総合評価の不確実性 と代替案の決定, 土木計画学研究発表会講演集 1, pp. 191 $\sim 202,1979$.

14）河上省吾・青島縮次郎：各種意識量の相対的重みづけの 試み, 土木計画学シンポジウム, pp. 24〜32, 1977.

15）五藤紳一郎：公共輸送機関の整備が通勤通学交通に及ぼ 寸影響记関する調查分析，名古屋大学修士論文，1978。

16）森杉寿芳・宮武信春・吉田哲生：騒音の社会的費用の計 測方法化関する研究，土木学会論文報告集，No. 302, pp. 113 124, 1980 .

(1981.5.12 • 受付) 